\title{
Association of mastocytosis with interleukin 31 gene polymorphism
}

\author{
Boguslaw Nedoszytko ${ }^{1}$, Monika Zabonta' ${ }^{1}$, Marek Niedoszytko², Magdalena Lange ${ }^{\text {1* }}$ \\ From EAACI Skin Allergy Meeting 2014 \\ Krakow, Poland. 18-20 September 2014
}

Mastocytosis is a rare disease characterized by activating KIT mutations and clonal expansion of mast cells (MCs) in tissues, particularly in skin and bone marrow. Symptoms of mastocytosis always correlate with the extent of MC infiltration and include urticaria pigmentosa, anaphylaxis, flushing, headache, diarrhea, osteoporosis and pruritus. Interleukin 31 (IL-31) is a new recently identified pruritogenic factor mainly produced by activated $\mathrm{T}$ cells, but also by mast cells. Recently published data indicated that IL-31 level is increased in adult patients with mastocytosis.

The aim of our study is to compare the frequency of -1066 G/A, -2057 G/A and IVS2+12 polymorphisms of IL-31 gene which upregulate gene transcription in mastocytosis patients and healthy control groups.

Using ARMS-PCR methods we analyze the polymorphisms of IL-31 gene in 240 mastocytosis patients and 110 healthy controls.

We have found that in comparison to the control mastocytosis patients have more frequently AA genotype in all three analyzed polymorphisms: -1066 AA: $17,7 \%$ vs $8,2 \%, p=0,02 ;-2057$ AA: $7,5 \%$ vs $1,1 \%, p=0,024$, IVS $2+12$ AA 63,6 vs $40 \%, p=0,007$. The presence of -2057 AA genotype more than $7 \mathrm{x}$ increase the risk of mastocytosis: $\mathrm{OR}=7,38(0,97-56.09) \mathrm{p}=0,05$.

In conclusion, results of our study indicate that mastocytosis could be associated with IL-31 gene polymorphisms

\footnotetext{
Authors' details

'Medical University of Gdansk, Department of Dermatology, Gdansk; Germany. ${ }^{2}$ Medical University of Gdansk, Department of Allergology, Gdansk, Germany.

Published: 11 March 2015

'Medical University of Gdansk, Department of Dermatology, Gdansk; Germany

Full list of author information is available at the end of the article
}

doi:10.1186/2045-7022-5-S1-P11

Cite this article as: Nedoszytko et al.: Association of mastocytosis with interleukin 31 gene polymorphism. Clinical and Translational Allergy 2015 5(Suppl 1):P11.
Submit your next manuscript to BioMed Central and take full advantage of:

- Convenient online submission

- Thorough peer review

- No space constraints or color figure charges

- Immediate publication on acceptance

- Inclusion in PubMed, CAS, Scopus and Google Scholar

- Research which is freely available for redistribution
C Biomed Central
C Biomed Central

(c) 2015 Nedoszytko et al; licensee BioMed Central Ltd. This is an Open Access article distributed under the terms of the Creative Commons Attribution License (http://creativecommons.org/licenses/by/4.0), which permits unrestricted use, distribution, and reproduction in any medium, provided the original work is properly cited. The Creative Commons Public Domain Dedication waiver (http://creativecommons.org/publicdomain/zero/1.0/) applies to the data made available in this article, unless otherwise stated. 